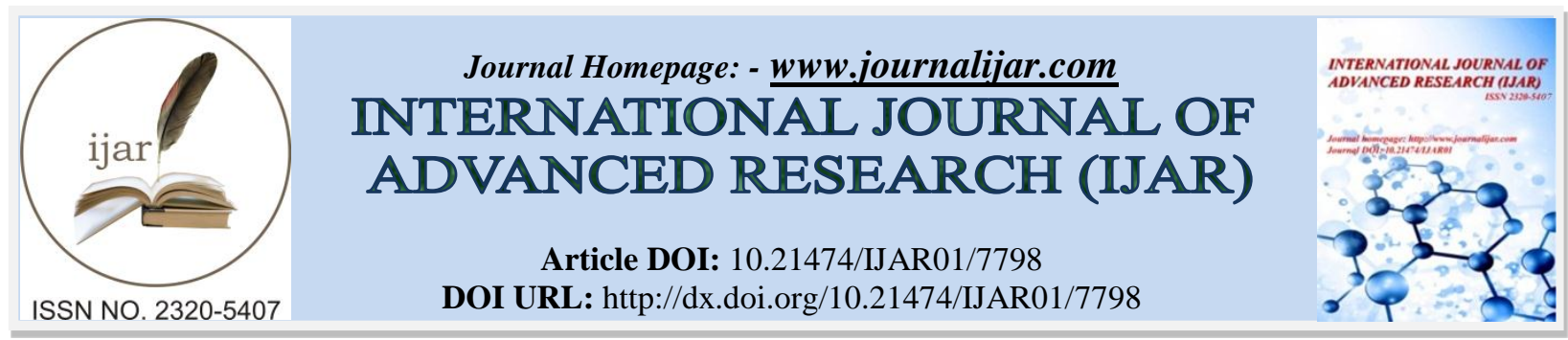

RESEARCH ARTICLE

\title{
INTEGRATING INDIGENOUS KNOWLEDGE PRACTICES INTO AGRICULTURAL EXTENSION EDUCATION IN LUANO DISTRICT OF CENTRAL ZAMBIA.
}

Wilmur Simatimbe, Emmy H. Mbozi and Lynette Hambulo.

\section{Manuscript Info}

Manuscript History

Received: 2 August 2018

Final Accepted: 4 September 2018

Published: October 2018

Keywords:

Indigenous Knowledge, Agriculture

Extension Education, intergration

\begin{abstract}
This paper is based on the study on indigenous practices carried out in Luano District and the explanatory factors influencing such practices in agriculture. The paper further discusses the possible ways of integrating indigenous knowledge practices of farming into agricultural extension education in Luano District. A descriptive phenomenological research design was used for the study. The data was collected using interviews from farmers and agricultural extension officers. The paper examined what indigenous knowledge agricultural extension officers integrated in their practices and the factors that influenced the use of indigenous knowledge in agricultural extension education. It further examined the use of indigenous knowledge in farming by the communities and the factors that influenced the practice in Luano District. Finally, the paper suggests ways indigenous knowledge practices would be integrated into agriculture extension education work in Luano District.
\end{abstract}

Copy Right, IJAR, 2018. All rights reserved.

\section{Introduction:-}

\section{Concept of indigenous knowledge}

Indigenous knowledge is often used to refer to traditional knowledge. According to Fleischacker (1992) cited in Gyekye, (1997), tradition refers to a "set of customs passed down over generations, and a set of beliefs and values endorsing those customs." On the other hand, Indigenous knowledge refers to what indigenous people know and do, and what they have known and done for generations - practices that evolved through trial and error and proved flexible enough to cope with change (Melchias, 2001 cited in Eyong, 2007). According to Haverkot (1991), indigenous knowledge is the actual knowledge of a given population that reflects the experiences based on tradition and include more recent experience with modern technologies. It is knowledge generated, developed and used by certain people in a certain area and not limited to indigenous peoples. It may include knowledge originating from elsewhere but has been internalized by local people through local processes of learning, testing and adaptation (Jaya, 2005). It is local knowledge unique to a given culture or society acquired by local people through the accumulation of experience, informal experiments and ultimate understanding of the environment in a given culture (Warren, 1987, Rajasekaran, 1993). In this paper, Indigenous knowledge practices refers to traditional or local knowledge and practices unique to a given culture or society. This definition is used to refer to small scale farmers in Luano District and the way they relate to their farming practices in relation to Indigenous knowledge as a valuable resource that has provided human kind with insights on how communities have interacted with their changing environment.

Research has shown that, Indigenous knowledge forms the basis for local level decision making in Agriculture, healthcare, food preparation, education, natural resources management, and is a host of other activities in rural communities (Warren 1991, Anaeto et al.2005, Asiabaka, 2009). In addition, it is a model for a healthy interaction 
with, and use of, the environment, and as a rich source to be tapped into in order to gain new perspectives about the relationship between humans and nature (Berkes et al, 2000). Indigenous knowledge is a potential source of creativity and enrichment embodied in several social and cultural identities, each of which expresses its uniqueness (UNESCO, 2002).

The Local people using this knowledge are well informed about their own situations, their resources, what works and does not work and how one change impacts other parts of their system. It is this knowledge local people use to make a living in a particular environment and adapt to meet new conditions. Simple as it may appear, indigenous knowledge practices represent mechanisms to ensure minimal livelihoods for the local people based on their needs as well as the quality and quantity of available resources (Anaeto et al, 2013).

Often times, Small-scale farmers are portrayed as unproductive, primitive, backward, conservative, resistant to change, lacking innovative ability, and even lazy (Atteh, 1989, IFAP, 1990,). This perception of small scale farmers tends to undermine their confidence in their knowledge and promote dependence. This integration of indigenous knowledge in agriculture extension advocated for helps to understand the 'emic' perspectives of local people to indigenous knowledge, recognize and appreciate the accomplishments of local farmers, help outsiders familiarize themselves with local conditions and increase the participation of farmers and their organizations in integrating, utilizing, and disseminating what already exists (Rajasekaran, 1991, 1993).

\section{Indigenous Knowledge and Agriculture}

Indigenous knowledge is rich in agricultural practices and techniques. Since time immemorial, indigenous peoples have developed and applied several farming techniques and have orally passed them from one generation to the next. Recent research has given valuable insights into how people use their own locally generated knowledge to change and improve agriculture through experience, informal experiments and intimate understanding of their environments which they apply in the various agricultural practices such as Indigenous soil preparation and planting materials, indigenous methods of controlling pests and diseases, indigenous methods of maintaining soil fertility, indigenous methods of controlling weeds as well as indigenous methods of harvesting and storage (Abiola et al, 2011). It is believed that indigenous knowledge has much to offer not only to those that depend on it but to modern industry and the world at large. Warren (1991) notes that Indigenous Knowledge has made a tremendous contribution to crop production by poor farmers. Okuneye and Ayinde (2004) cited in Anyira (2010) adds that small scale resource farmers stick to their local knowledge and farming practices, because modern technologies can only be successful and sustainable if indigenous knowledge is taken into consideration; for example Ridges are widely used to grow vegetables, maize, groundnuts, Irish potatoes, sweet potatoes, legumes and many others. On plateaus, some farmers make ridges with flat top and on hilly areas round-top ridge systems are used. Contoured ridges prevent soil erosion and retain some moisture that is good for plant growth (Kayombol et al., 1999). Trash lines formed by placing crop residues in lines, across the farm plot are widely used to impede runoff, enhance infiltration if carefully and effectively done. Mostly, trash lines are constructed from sorghum and millet clovers that are slow to decompose and are of lower palatability to livestock than maize clovers. They are destroyed by ants and termites and can withstand deluges of water. Since they are permeable they leak water. Decomposition of trash line material increases soil fertility. In primary forests, log lines are common on recently cleared farm plots (Kayombol et al., 1999).

Composting plant residues and addition of animal manure like cow dung to revamp the land's fertility is yet another practice learnt from indigenous knowledge. The resultant high content of incorporated organic matter increases soil fertility and promotes rainfall infiltration. Mulching is used to conserve soil and water, to maintain soil fertility and to reduce weed growth. These biodegradable fertilizers have little adverse effects on the food chain compared to chemical fertilizers. Today, villagers apply nitrogenous fertilizers to cash crops like coffee, cocoa and banana and hardly to food crops. Often, locals complain that food grown with fertilizers does not taste good (Eyong, 2003). Traditionally prepared bans and bush sheds have served as food storage places throughout seasons. Sometimes, collected seeds are stocked in walls of houses; maize is smoked in kitchens as well as some plant species are used to keep away weevils in addition to many other storage techniques (Eyong, 2003).

The small scale farmers in Luano District of Central province among whom the field work was conducted, are the indigenous people whose livelihoods have always been dependent on the land. The fact that these people have a great attachment to the land and do not see themselves separate from the land validates belief and confidence in their 
concept of the environment as a determinant of their culture and behavior. Life for them is not viewed in an individualistic way but in mutuality and "all connectedness.

\begin{abstract}
Modern knowledge versus indigenous knowledge
Modernity and tradition are two concepts that are relevant to this study because they are often perceived as polar paradigms of acquiring knowledge about the universe. These concepts influence the way people perceive culture and make choices, and are very pertinent in relation to agriculture in a Zambian context. Modernity as defined by Gyekye, (1997) is the 'hub' of "consultation for the non western societies wanting to gain inspiration and knowledge for models of thought and action for developing their societies. Modern agriculture uses western education which heavily relies on scientific knowledge. This kind of knowledge has held a central role and attained a dominant position in our developing societies, but we cannot ignore the fact that alternative valid knowledge systems exist. This paradigm of development was roundly condemned for its Eurocentric bias, its notion of linear stages of growth, and its positivist reduction orientation to development based on indices of economic growth (Howard, 1994).
\end{abstract}

Traditional knowledge is the way of knowing similar to that of Western science in that it is based on an accumulation of observations, but it is different from science in several other fundamental ways (Berkes et al, 2000). However, European colonization has eroded and destroyed much of this traditional knowledge by replacing it with Western educational and cultural systems as the only valid source of knowledge. The imposition of Western scientific ideas and methods not only causes disruption to existing social and economic relationships, but also spoils the local knowledge. Other scholars argue that an approach based on reductionism as helpful as it might have been might no longer be sufficient to analyse and understand higher levels of complexity (Kellenberger, 2004; Van Regenmortel, 2004). Laccarino, (2003) adds that scientists work only at specific levels of analysis. The theories formulated at each level are based on key observations, and can only explain specific fact. Therefore, integration of methods and results from different approaches and levels of analysis can become essential. There is little doubt that modern science can gain a lot from such integration. Bohm, (1996) forwards that, by acknowledging the uniqueness of each knowledge system, we can go well beyond a mere pluralist approach to knowledge. Dialogue can become a tool for social cohabitation, as well as for discovering and enhancing knowledge. It can catalyze the development of shared meanings, which are key factors in binding people and societies together as vehicles of social cohabitation.

\title{
Indigenous knowledge, extension education and Agriculture
}

Extension is a non-formal educational function that applies to any institution that disseminates information with the intention of upgrading knowledge, attitudes, skills and aspirations of the people (Rivera \& Qamar, 2003). Anaeto, (2013) uses the term extension education to refer to a system of education which involves behavioral change with the aims of helping people appreciate their circumstance and strive to change for better. Agriculture extension education is the application of scientific research and new knowledge to agriculture through farmer education (NAESS, 2016). Agriculture extension education as an educational process, involves working with the people along the lines of their felt needs and interest, discovering their real needs to make and enhance their living, and to improve their physical surrounding. It is a dynamic process which brings about change in what people know, change in how they react to situation and change in what they can do with their hands (Ani, 1999). Extension education is more than just dissemination of information on innovations but is premised on active participation of people who are naturally endowed with the power to change themselves mentally and their environment physically, and have the ability to learn new attitudes, new skills, new methods and ability to make decision, construct or alter their physical surrounding (Ani, 1999).

In spite of all the importance of agricultural extension to national building, the failure of the various extension delivery approaches to effectively engineer significant and sustainable agricultural growth has become a major concern to all stakeholders, thus the shift in recent years in the understanding of the practicalities for empowering farmers, through effective extension service.

Zambia like all other African countries is part of the current economic and ecological crisis, evidenced in population increase, changing weather patterns and degradation of the earth that is posing a great challenge to agricultural output (Sakayombo, 2014). In view of these ecological crises, re-thinking of the way agricultural technology is delivered to farmers has become necessary (Madukwe (2006). If public extension systems are going to be effective in improving rural livelihoods, then they must change their focus, structure and approach (Swanson, 2008). The dominance of the Western knowledge system has largely led to a prevailing situation in which indigenous knowledge is ignored and neglected and since indigenous knowledge is the information base of a society, which 
facilitates communication and decision-making, it then becomes important when one critically looks at farmers as co-advocates of knowledge especially indigenous knowledge. Posey (1985) observed that a strong relationship exist between indigenous knowledge and sustainable development and this offers new models for development that are both ecologically and socially sound. Development activities that work with and through indigenous knowledge and organizational structures have several important advantages over projects that operate outside them (Madukwe, 2006). Indigenous knowledge provides the basis for grassroots decision-making, much of which takes place at the community level through indigenous organizations and associations where problems are identified and solutions to them are determined (Warren, 1992). Much of the world's biological and agricultural diversity is in the custody of farmers who follow age old farming and land use practices (Old field and Alcorn, 1991). Agricultural extension is the hub of any agricultural development programme and its ultimate goal is to improve the socioeconomic well being of farmers, including all those who can benefit from its services.

The success of extension programs will be determined to a large degree by the ability of the extension worker to be qualified and competent since the whole extension process is dependent on them to transfer new ideas and technical advice to the rural community (Neda Tiraieyari, (2009). Extension therefore is a human process in which technical information are integrated and used to help rural people achieve their potentials (Boone, 1990). Since the most important interface in technology transfer is human; therefore the key point in technology transfer is how to transform the rural people into a new idea (Jon Chang Hong, 1994). Furthermore human attitudes and behaviors are influenced by their society's culture, it is therefore important for extension workers to have knowledge on the culture of the people before embarking on transferring technologies to them. In fact in all societies there are accepted ways of doing things and these ways are related to the culture of the society. Okley and Garforth (1985) stated that an extension worker would be more effective if he understands the cultural background of the people with whom he works. This will enable him offer advice and useful information that fits in with the culture of the society, and also use the culture of the society to the benefit of his work. His failure to understand rural people' culture will result in under- used extension programs.

\section{Integrating indigenous knowledge practices in agriculture extension education}

Integration refers to recognizing indigenous knowledge and harnessing it for use in extension education to disseminate local content, increase the relevance of the information to local development as well as to inventory all relevant resources (Anaeto, et al, 2013). Extension needs to go beyond technology transfer to developing skills and knowledge of farm families for sustainable agriculture and rural development further advises (Madukwe, 2006). There should be a paradigm shift from the conventional method of technology transfer via training and visit, face to face contact as well as the top-down approach of generating technologies and innovations meant for farmers to the bottom-top approach which would see the farmer whose knowledge counts, as the focal point more than that of the scientist (Williams, 1978, Asiabaka, 2010). It is in the face of this that indigenous knowledge becomes handy especially in its ability to promote sustainable development. Activities that aim to benefit the poor, need to consider indigenous knowledge in their design and implementation stages. This could be achieved through new paradigms which tend to involve those who possess indigenous knowledge (small scale farmers' knowledge) in the development activities. The new paradigms use approaches and methods of promoting indigenous knowledge through participatory approaches like farmer field school (FFS), farmer study circle (FSC), farmer meeting groups (FMG), Household approach or family approach system focus group discussion (FGD), and facilitation cycle (Madukwe, 2006; Rajasekaran, 1993; Asiabaka, 2010). These approaches and methods bring about fuller participation of farmers groups and strengthen their capacity to identify their needs, to set priorities and demand appropriate services. Unfortunately, many indigenous knowledge systems are at risk of becoming extinct because of rapidly changing natural environment and fast pacing economic, political and cultural changes on a global scale. Practices vanish and disappear because of the intrusion of foreign technologies. The tragedy of the impending disappearance of indigenous knowledge is most obvious to those who have developed it and make a living through it. The implication of this therefore is the need for a new paradigm shift which calls for integration of indigenous knowledge system into extension education so as to help protect, improve, and sustain the peoples local knowledge by involving them in programmes meant to develop them. There is a need for extension policy makers to strengthen the linkage between research, extension and farmers. Fortifying this linkage is very important because despite continuous importance given to the linkage while developing, disseminating and utilizing sustainable agricultural technologies, several socio-political and institutional factors act as constraints for such an effective linkage (Anaeto et al, 2013). 
Apart from this, knowledge of adult learning principles are important to the practice of extension work. The extension worker can have all the technology but if he does not understand adult learning process, his efforts will be in vain. Brookfield (1987) puts across the following six principles essential for facilitating learning which could be of use to extension officers;

1. Farmer participation in learning should be voluntary;

2. Effective facilitation should be characterized by a respect among participants for other's self-worth;

3. Facilitation should be collaborative;

4. Praxis (practice rather than theory) should be placed at the heart of effective facilitation;

5. Facilitation should be based on critical reflection which involves examination of one's belief and premise underlying the learning taking place; and

6. That facilitation should aim to nurture self-directed and empowered adults (farmers). Knowledge of adult learning principles by extension education officers will help to deliver and evaluate learning of small scale farmers and eventually successful implementation of extension education programmes.

\section{Problem statement}

The need to integrate Indigenous Knowledge in agricultural extension education in Zambia to reflect the local cultural settings cannot be over emphasized. Indigenous Knowledge offers great opportunities for improved agricultural production and sustainable food security as it is the basis for local-level decision-making in many rural communities (Anyira, 2010). Indigenous knowledge has value not only for the culture in which it evolves, but also for scientists and planners striving to improve conditions in rural localities. The knowledge set is influenced by the previous generations' observations and experiment and provides an inherent connection to one's surroundings and environment. Research shows that Indigenous knowledge is being gradually being recognized as an alternative knowledge that can be used in the preservation of the environment (Warren et al.; 1989; Sillitoe, 2000; Breidlid, 2013) cited in Sakayombo (2014). However, despite the realization of the importance of indigenous knowledge to sustainable development, we know little about the indigenous knowledge in agriculture and how much of it is integrated into agriculture extension education. It is for this reason that this study sought to explore ways indigenous knowledge was being integrated in agriculture extension education in Luano District of Central province in Zambia.

\section{Research Questions}

The study was based on the following research questions;

1. What aspects of indigenous knowledge do agriculture extension workers integrate in agriculture extension education in Luano District?

2. What factors influence the use of indigenous knowledge in agriculture extension programmes in Luano District?

3. In which ways do the farming community use indigenous knowledge in Luano District?

4. What factors influence the use of indigenous knowledge by the farming community in Luano District?

5. In which way would the use of indigenous knowledge be integrated in agriculture extension education programmes in Luano District?

\section{Methods:-}

\section{Study site:-}

Luano is one of the newly created districts in Zambia lying South of Mkushi in Central, Zambia and its geographical coordinates are $14^{\circ} 7^{\prime} 0^{\prime \prime}$ South, 30 $10^{\prime} 0^{\prime \prime}$ East. It is one of the remote districts in Zambia characterized mainly by mountains forming the Muchinga escarpment. The District draws its name from Luano valley which extends to the Great Rift Valley. The district covers a surface area of 9643.54 square kilometres. 


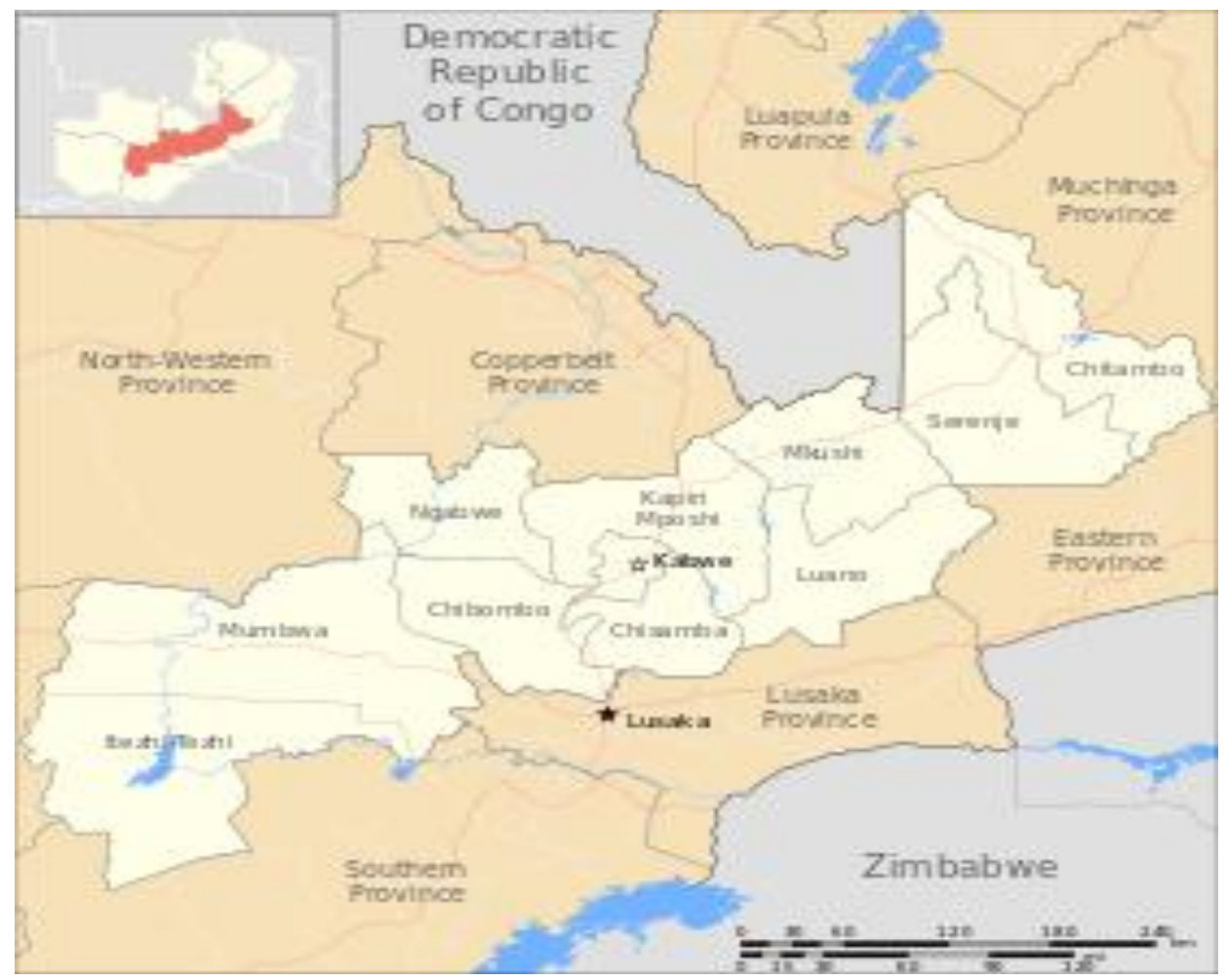

Location of Luano District in Zambia

The district is characterized by poor road network making it difficult to access most of its parts for service delivery. This implies that use of indigenous knowledge is still predominant. According to the (2012) Census of Population and Housing, Luano has 37,204 people with 3,650 households, and a population growth rate of two (2\%) percent per annum. Of the total population, 18,816 are males while 18,388 are females.

Lala is the main language spoken in Luano although there is also Swaka which is mostly used in Chikupili chiefdom. Tonga is yet another language that is spoken in Luano, as a result of migration from Southern Province in search of land for farming. These ethnic groups vary in culture, language, socioeconomic status, and religion. Extension workers are dealing with these ethnic communities to transfer advice and new technology. Based on the reports above, it can be seen that this population is big and that it cannot be overlooked in the activities of national development. There is great urgency for extension service and extension organizations to reach to reach out to these groups in order to serve them effectively.

Agriculture is the main economic activity for people in both the valley and the plateau largely small scale farmers who grow mainly maize, soya beans, groundnuts, cassava, sweet potatoes, sorghum and finger millet are some of the other crops. In Luano valley, many people have settled near the river banks where they grow crops such as maize, rice and bananas. Apart from this, the people also keep cattle, pigs and goats, in addition to rearing chickens.

For agricultural purposes, at the time of the study Luano was divided into 3 blocks and 8 camps. The Eight camps included Chikupili, Matuka, Kaundula, ching’ombe, Mboroma, Lunsenfwa, Old Mkushi and Kabololwe.

\section{Research Design}

The study used a descriptive survey research design

\section{Data collection \\ Population}

The population of the study included small scale farmers estimated and all agriculture extension officers in Luano District and agriculture officers. 


\section{Sample size and sampling technique}

A sample of 40 farmers and 10 extension officers was used for the study. The famers were selected using random sampling technique from 4 purposively selected camps. The extension officers were also purposively selected.

\section{Instrument}

Interview guide was used on 40 farmers from 4 camps, Chikupili, Matuka, Old Mkushi and Kabololwe and all agriculture extension officers. The farmers were drawn from 5 camps purposively selected. The respondents were selected using purposive sampling based on experience in farming. Data was collected in 4 camps using in depth interviews and focus group discussions. The nature of the methods employed for data collection enabled comparisons among farmers and fact checking. The methods sought to find the indigenous practices used in agriculture and to find out whether extension officers included indigenous knowledge in the meetings they organized. Both male and female were considered for the in-depth interview. Selection of the Focus Group Discussion participants included an equal number of males and females of variable age groups.

\section{Procedure}

The researcher first sought permission from relevant authorities to carry out a study in this area. The researcher then sent out requests on contact telephone to extension officers who could not be accessed easily to make appointments for meetings. The farmers were also visited randomly. The farmer who was not found or willing to respond to the interview was left out. Focus group discussions were organized with selected individuals with the information required.

\section{Results:-}

\section{Indigenous practices associated with agriculture in Luano District}

The Extension workers and farmers indicated that use of indigenous knowledge in agriculture is high in Luano District. One extension officer pointed to the practice of basal fertilizer application and said,

'basal fertilizer is supposed to be applied during planting to promote root formation, for example in maize, but farmers wait until the maize is at knee high, and then mix basal dressing with top dressing fertilizers'.

The farmers asked on the indigenous practices indicated that they kept seed dusted with ash in sealed containers for the next season, grew local plant varieties like kapya bwangu, growing of the traditional maize varieties on ant-hills, growing of traditional relishes crops like umulembwe (traditional okra), Chibwabwa (pumpkin leaves), sunta (cleome gynandra) among others.

\section{Factors influencing the practice}

On factors influencing the practice, the extension officers indicated that people use indigenous knowledge because that was what they were inducted in by their parents and they could easily exchange ideas and planting materials among themselves and tried out what they were told. The had this to say on what influences the practices;

The use of indigenous knowledge is very much prevalent because it is very easy to find planting materials. The farmers do not need to travel to town to access the seed. In some cases, farmers don't even buy seed, for example relish crops like delele (okra), ibondwe (amaranthus spp). They pick seeds and keep them then broadcast them at the on set of the rain. In some cases, traditional relishes crops, just grow on their own in the field and farmers pick for home consumption.

The farmers indicated that, what they eat and do in relation to agriculture stem from the induction they were given by their parents from childhood which they also pass to the next generation in the same way. The young generation learns through observation and apprentice. One farmer said

Ifingi ifintu, twalemomona kunkulo ifyo balecita, nefwe twatampa ukucita.

Literally meaning, most of the things we do, we learnt from our parents and we started practicing them. Another farmer said,

Lintu umulumendo akula, aupa, tulamupela nokumulanga imbuto kwati kapya bwangu yakubyala nokumulangilila ifya kuibyala nefibombelo kutila ulupwa lwakwe lwikafwa nensala.

Literal meaning is the moment a boy becomes of age and marries, we present him with seed, hoe and advise him on how to grow this seeds like kapya bwangu (traditional maize variety) so that his family does not starve. One more farmer said 
Imbuto shacimuntu kwati kapya bwangu na gankata, tatushitisha iyo, tulaipeleshanya fye kutila imbuto ipwililila. Elo ngamataba yacimuntu yalilowa kucila imbuto tushita, ngatwa sombola, tatushitisha amataba yalya, yakulya fwebene, alya eyo tushita imbuto yakushitisha.

Meaning, the traditional seed varieties like kapya bwangu (early maturing variety) and gankata maize varieties we don't sell but we give each other freely in the community so that the variety does not finish up completely. Besides that, traditional maize is sweeter than the hybrid maize seed we buy. When we harvest, we don't sell the traditional maize, that's what we use for home consumption and we sell the hybrid maize.

In line with this, one extension officer indicated that

'there is a strong attachment of agriculture to ancestral knowledge by farmers, they still believe that 'gods' exist. People still pray for the rains at the shrine for the good harvest and perform rituals to celebrate their harvest. Chibwela Munshi annual traditional ceremony celebrated by the Lala, Bisa and swaka people of Luano, Mkushi and Serenje is conducted to thank 'gods' for the harvest of that particular year performed with rituals. Community members feel poor rains experienced in the recent past were a sign of god's anger due to bad behavior currently being exhibited by the young generation. This has eventually led to poor harvests.

\section{Extent of integration}

\section{Use of indigenous knowledge in agriculture extension education}

In determining the extent indigenous knowledge was used in extension education programmes in Luano district. The respondents were asked to indicate what agriculture activities they were engaged in and the source of knowledge that guided their practice. Their responses are as indicated in table1:

Table 1:-Shows The Sources Of Knowledge For Agriculture Practices In Luano District.

\begin{tabular}{|c|c|c|c|c|}
\hline Sector & Subject area & $\begin{array}{l}\text { Agriculture practice learnt } \\
\text { through local knowledge }\end{array}$ & $\begin{array}{l}\text { Agriculture practice } \\
\text { Learnt through } \\
\text { extension education }\end{array}$ & $\begin{array}{l}\text { Extent of } \\
\text { integration in } \\
\text { Agriculture } \\
\text { Extension } \\
\text { Education }\end{array}$ \\
\hline \multirow[t]{2}{*}{ Crops } & $\begin{array}{l}\text { traditional relish } \\
\text { crops }\end{array}$ & $\begin{array}{l}\text { mankolobwe, } \\
\text { mulembwe,chibanga, } \\
\text { cowpeas, Ntoyo, sweet } \\
\text { potatoes and cassava }\end{array}$ & $\begin{array}{l}\text { cowpeas and sweet } \\
\text { potatoes during } \\
\text { shows }\end{array}$ & $\begin{array}{l}\text { Out of } 9 \\
\text { traditional relish } \\
\text { crops, only } 3 \\
\text { were taught by } \\
\text { representing } \\
(33 \%)\end{array}$ \\
\hline & Cereal crops & $\begin{array}{l}\text { sorghum, millet, traditional } \\
\text { maize varieties like kapya } \\
\text { bwangu and gankata }\end{array}$ & $\begin{array}{l}\text { hybrid maize and } \\
\text { sorghum varieties }\end{array}$ & $\begin{array}{l}\text { Integrated only } 2 \\
\text { out of } 5 \text { crops } \\
(40 \%)\end{array}$ \\
\hline \multirow[t]{4}{*}{$\begin{array}{l}\text { Agriculture } \\
\text { practices and } \\
\text { processes }\end{array}$} & preservation of food & $\begin{array}{l}\text { Processing, preparation and } \\
\text { preservation of traditional } \\
\text { food }\end{array}$ & $\begin{array}{l}\text { value addition on } \\
\text { some food }\end{array}$ & $\begin{array}{l}\text { Integrated } \\
\text { preparation 1out } \\
\text { of } 3 \text { processes } \\
(33 \%)\end{array}$ \\
\hline & Seed protection & $\begin{array}{l}\text { Smoking seeds to protect } \\
\text { them from weevil }\end{array}$ & $\begin{array}{l}\text { promoting use of } \\
\text { hybrid seeds }\end{array}$ & Nil \\
\hline & Planting & $\begin{array}{l}\text { Maize, ground nuts, cowpeas, } \\
\text { millet, sorghum, ubuleya } \\
\text { (ntoyo) }\end{array}$ & $\begin{array}{l}\text { only for maize and } \\
\text { other cash }\end{array}$ & $\begin{array}{l}1 \text { out of } 6 \text { crops } \\
(17 \%)\end{array}$ \\
\hline & Crop protection & $\begin{array}{l}\text { rely on traditional ways of } \\
\text { weeding, use ash from mopani } \\
\text { trees to protect crop against } \\
\text { aphids (inda) }\end{array}$ & $\begin{array}{l}\text { use of chemicals to } \\
\text { control weeds and } \\
\text { pests }\end{array}$ & Nil \\
\hline Soil & Soil identification & leant it locally & not taught & Nil \\
\hline
\end{tabular}




\begin{tabular}{|l|l|l|l|l|}
\hline & Soil management & manuring learnt locally & $\begin{array}{l}\text { Use of inorganic } \\
\text { fertilizers } \\
\text { Crop rotation }\end{array}$ & Nil \\
\cline { 2 - 5 } & loss of soil fertility & $\begin{array}{l}\text { learnt traditionally through } \\
\text { reduced yields }\end{array}$ & not taught & Nil \\
\hline Livestock & Disease control & $\begin{array}{l}\text { use of local herb Katangala to } \\
\text { control ticks (bubala) }\end{array}$ & $\begin{array}{l}\text { advise given on } \\
\text { remedies }\end{array}$ & Nil \\
\cline { 2 - 6 } & Feeding & use of natural grassland & not taught & Nil \\
\cline { 2 - 5 } & $\begin{array}{l}\text { Identification of } \\
\text { good grazing } \\
\text { pastures }\end{array}$ & learnt by observing elders & not taught & Nil \\
\cline { 2 - 6 } & \begin{tabular}{l} 
pasture management \\
\cline { 2 - 5 }
\end{tabular} & learnt by observing elders & not taught & Nil \\
\hline
\end{tabular}

In relation to the extent extension workers integrated of indigenous knowledge, most of them indicated that they used it when teaching conservation farming although it has been observed that farmers are reluctant to adopt the conservation farming. One extension officer said,

I believe use of indigenous knowledge is to promote sustainable agriculture and I teach conservation farming to promote that but farmers are resistant to adopt it. They say the practice is too involving and it promotes use of chemicals for weed control which destroys their soil. One farmer said,

Ba extension batweba ukobonfya imiti mumushili, ine mumabala yandi, imiti nshile fwaya iyo, mpantu shilaonaula umushili, konawila kumo nemilembwe tulya.

Literally meaning 'extension workers advise us to use chemicals in our fields, as for me, I don't want to use chemicals because they spoil the soil together with other traditional relish crops that we eat like okra'.

Another extension worker said that

I use the indigenous knowledge during nutrition programmes when promoting value addition on the farm products like frying of sweet potatoes.

Some extension workers indicated that indigenous knowledge practices related to agriculture was integrated in the District through exhibitions during agricultural shows. The farmers are encouraged to exhibit their traditional crops and indigenous animal breeds to provide a platform for exchange of ideas with other community members on the value of the products.

Factors influencing integration of Indigenous Knowledge in Agriculture extension education

The study established four main factors that influenced the integration of indigenous knowledge in agriculture extension education in Luano among them were; 

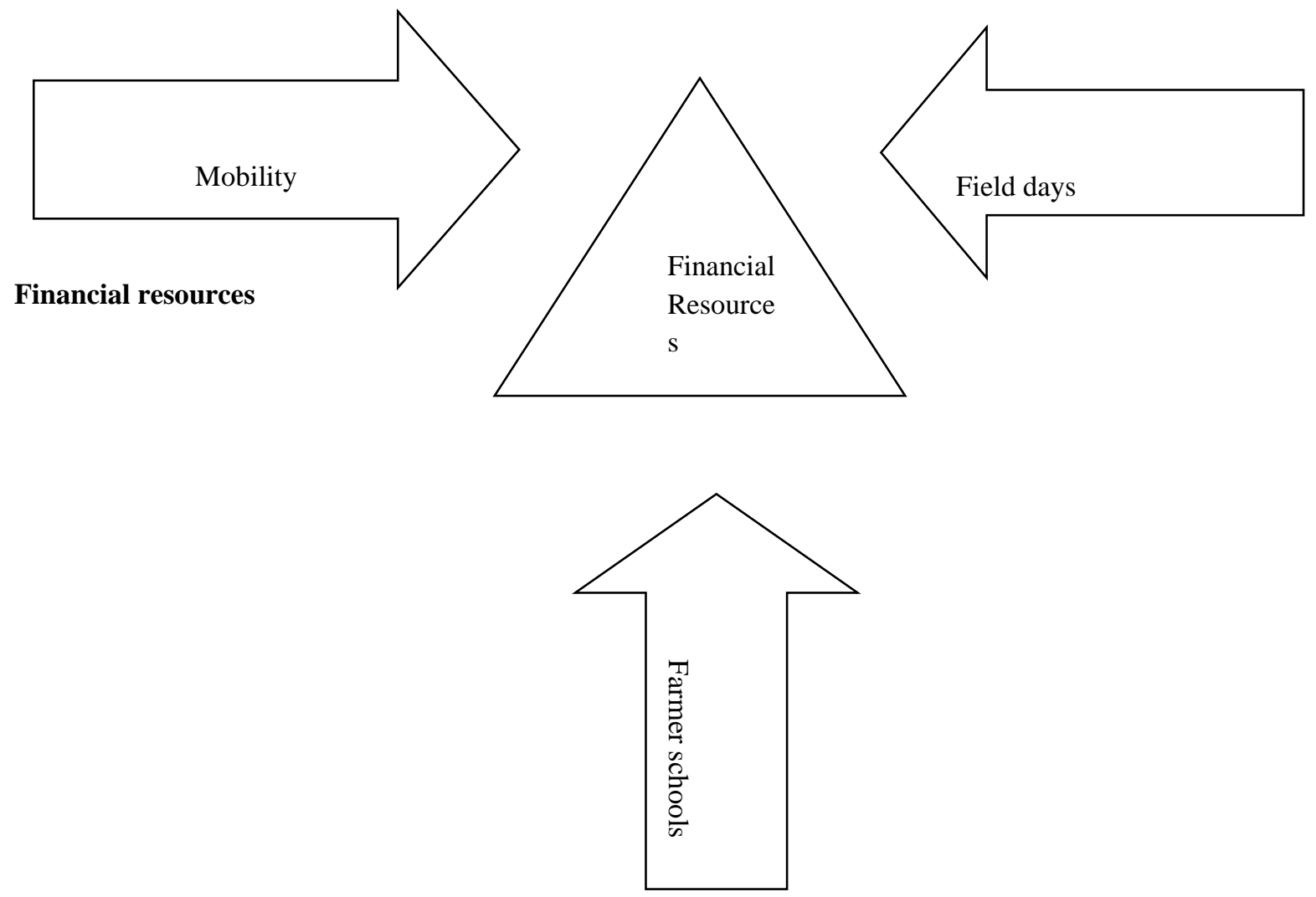

Training of extension worker
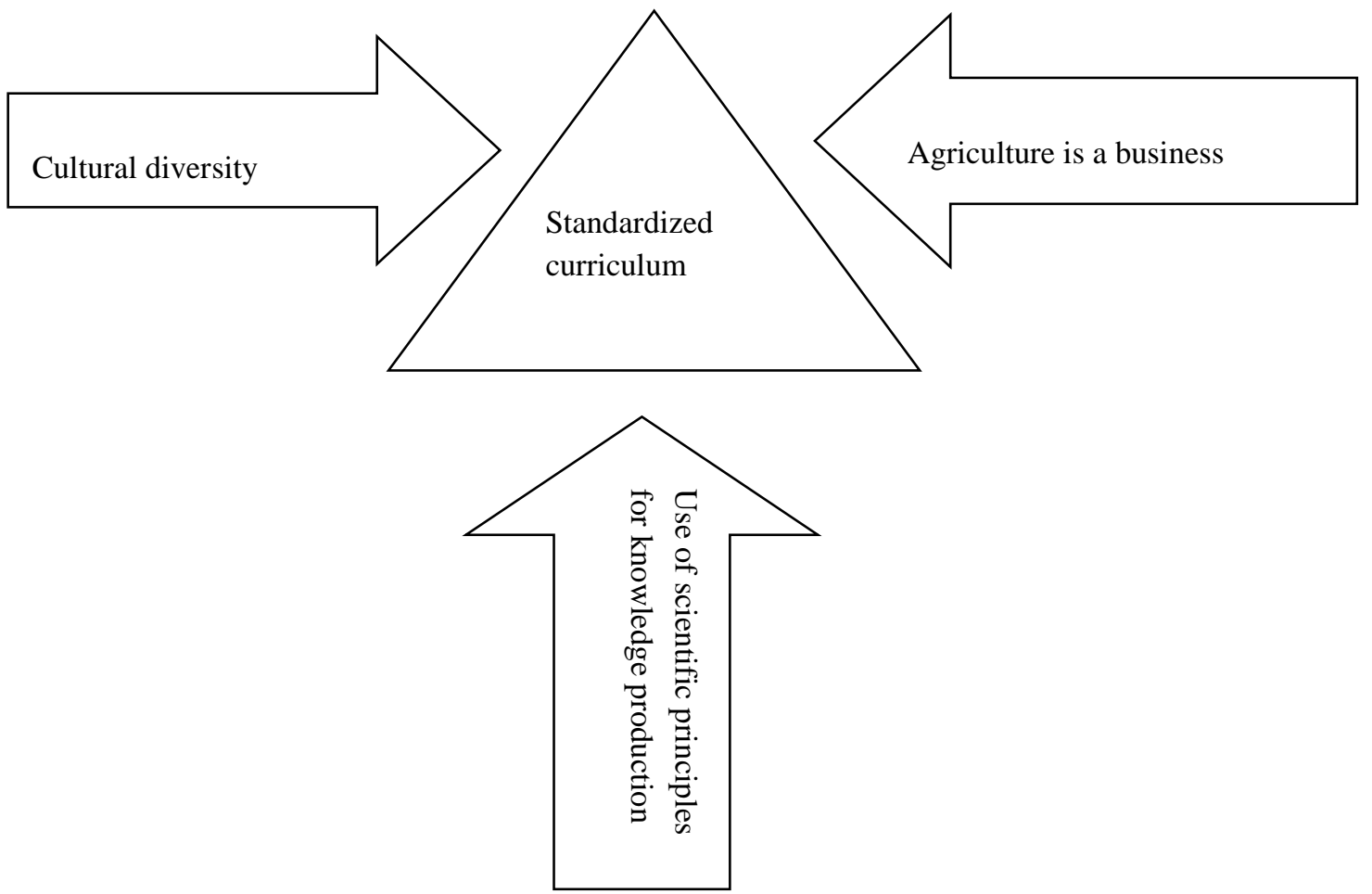


\section{Perception of indigenous knowledge.}

The way indigenous knowledge was viewed by extension officer influenced its integration in agriculture extension. The views of extension workers have been presented with pseudo names of extension workers are used to present views of extension officers;

Bwalya said 'indigenous knowledge is painted black by many people, as being irrelevant to modern life, it is assumed that those that still want to practice traditional methods of agriculture are backward.

Mwanza said, 'bunang'ani fyee, meaning its just laziness'.

For Mumbi this is what he said,

'use of indigenous knowledge in extension education work is out of interest and not a mandate. There is no deliberate programme pointing to the necessity of recognizing indigenous knowledge in our service provision. This eventually made extension workers relax and lose interest in this aspect.'

When farmers were asked as to why extension workers use the indigenous knowledge in their teaching, the majority did not know the reason why extension workers did not integrate indigenous knowledge. Others indicated that they see no value of promoting indigenous knowledge. One of them said

'bambi balanda ati, tapapo bukumo mukubonfya ulwishibo kufuma ku fikolwa'

Meaning, 'others say, there is no value of using knowledge which is passed on from older generations'.

Some indicated lack of knowledge by extension workers. One farmer openly said

"kukana ishiba. Ba extension banomba baiche, tapapo beshibe penkulo shakale. Nabo bafwile ukusambilila'

The literal meaning of this is that the 'current extension officers are young, they don't know anything about indigenous knowledge, they also need to learn.'

\section{Suggestions for integration}

The study established three ways in which indigenous knowledge practices could be integrated in agriculture extension education. One of the suggested ways is to review the curriculum for agriculture training to include indigenous Knowledge. This would expose the extension workers to appreciate local knowledge. The current extension workers might have been raised in urban areas and have no idea of using experience from the old folks in their work. They might have found themselves in the field of agriculture just for the sake of getting a job.

The other suggested way is to promote use of experience. Agriculture extension workers should be encouraged to learn from the farmers' experiences. They should be good listeners and be patient as they offer advice so as not to close up ideas from the farmers. They should be encouraged to learn from community members and eventually they will appreciate what farmers do.

One other way in which indigenous knowledge could be integrated is through use of traditional leaders. One farmer stated that "bacilolo naba kankomba kuti baafwilisha sana mumulimo uyu uwaku bomfya lwishibo twasambilila kunkulo sheshu mu agiculture. Pantu kwena ulwisho ulu tulalubomfya nangula ba agriculture tabalubomfya". This literally means village headmen and chiefs can be of great help in integrating knowledge learnt from tradition in agriculture, for we are using this knowledge in our practices even if agriculture extension officers do not promote it.

\section{Discussion:-}

The findings showed that the use of indigenous knowledge practices in agriculture in Luano district is still prominent. This could be seen in various ways among them; use of traditional varieties of crops, use of traditional relish crops, food processing, preservation of seed for next farming season, ability to predict soil fertility, disease control in animals, identification of good grazing areas among others. Indigenous knowledge practices are a complete package that brings out a variety; for example, indigenous knowledge on food crops is wide compared to hybrid species and varieties. Besides high nutritive value, indigenous plants are tasty compared to hybrids. To make hybrid plants tasty, spices have to be added whereas some indigenous relish plants like African cabbage (Cleome Gynandra) have a bitter sometimes peppery flavor similar to mustard forming an important part of diet. These findings resonate well with the report by (Abiola et al, 2011) when they say farmers adopt a wide range of indigenous agricultural practices based on generations of experience, informal experiments and intimate understanding of their environments which they apply in the following agricultural practices; indigenous soil 
preparation and planting materials. Indigenous methods of controlling pests and diseases, indigenous methods of maintaining soil fertility, indigenous methods of controlling weeds as well as indigenous methods of harvesting and storage.

The findings of the study indicate that indigenous knowledge is wide but there is very little integration in agriculture extension education in Luano. Agriculture extension officers integrate indigenous knowledge practices mainly through conservation farming and agriculture shows although farmers have been reluctant to adopt conservation farming owing to its high labor needs and that it uses chemicals for controlling weeds and pests. Agriculture extension workers should promote use of indigenous knowledge from the nutrition point of view and they should also realize that it is not easy to try out every crop in the laboratories before the information could diffuse out to the community. The chemicals used have residual effects and have negative effects to biodiversity. Based on the experience, farmers know what they want this is why they hesitate to adopt some practices.

The challenge of lack of training for agriculture extension officers to appreciate indigenous knowledge in their practice has adversely affected its integration into agriculture extension education. Research has shown that the success of extension programs is determined largely by the degree to which the extension worker is qualified and competent since the whole extension process is dependent on them to transfer new ideas and technical advice to the rural community (Neda Tiraieyari (2009). If indigenous knowledge is not exploited, its relevance will remain un tapped and limits other sustainable techniques from being exploited for adaptation as it is regarded as a source of many scientific techniques and practices. Madukwe (2006) cited in Anaeto et al, (2013) refers indigenous knowledge to be the information base of a society, which facilitates communication and decision-making.

The financial resource inadequacies for mobility is yet another big challenge which has left the extension officers helpless. Their activities are hijacked by those that have means thereby silencing the voices for local people and thus indigenous knowledge transmission. Dependence on seed and chemical companies for financial support during field days and demonstrations is killing the little remaining knowledge, practice, crop varieties and animal breeds. This is because the sponsors of field days and demonstrations are given more privileges to promote their products which are of western values and thus marginalizing their knowledge. Undermining farmers' confidence in their traditional knowledge can lead them to become increasing dependant on outside expertise (Richards, 1985; Warren, 1990).

The agriculture extension education should acknowledge indigenous knowledge as a complementary source of knowledge that improves the life of the people as opposed to concentrating on agriculture as a business. Integration of indigenous knowledge could be achieved through review of curriculum design to include components of Indigenous knowledge and promotion of experiential learning which could be achieved through participatory research. In order to sustain the practice, involvement of traditional leaders could enhance use of indigenous knowledge in agriculture in order to tap into the main method of transmission.

\section{Conclusion:-}

The study established that use of indigenous knowledge practices was still prominent in Luano District. The factors that influenced its prevalence was mainly the mode of transmission which was so strong among the community members. Indigenous knowledge was mainly transmitted through observations, imitation, apprenticeship and induction. This mode of transmission cemented its prevalence in the area. Despite the prominence of the practices, its integration into agriculture extension education still lags behind owing to inadequate financial resources, training of officers and perception of indigenous knowledge. The study proposed that the curriculum for the training of agriculture extension officers be reviewed to incorporate indigenous knowledge education. This will enable the officers to appreciate the knowledge and value the experience of their clients. The study also proposes the use of traditional leaders in their work for their teachings to be easily accepted. 


\section{Reference:-}

1. Anaeto, F.C., Asiabaka, C.C., Nnadi, F.N., Aja, O.O., Ajaero, J.O., Ukpongson, M.A., and Ugwoke, F.O. (2013). Integrating indigenous knowledge system in extension education: The potential for sustainable agricultural development in Nigeria. Research Journal of Agriculture and Environmental Management. Vol. 2(11), pp. 332-340.

2. Boone, E. J. (1990). Crossing Lines. Journal of Extension. 28 (3). www.joe.org.journalof Extension. Accessed on $25^{\text {th }}$ October, 2007.

3. Cohen, J. (1997). Statistical Power Analysis for the Behavioral Sciences (2nd ed.). Hillsdale, NJ: Lawrence Erlbaum Associates.

4. Jon Chang Hong. (1994). Technology Transfer and Human Resource Development. Emerald Full text. 26 (11):17-21.

5. Neda TIRAIEYARI (2009). The Importance of Cultural Competency for Agricultural Extensionworker in Malaysia, Uluslararast Sosyal Ara_ttrmalar Dergisi, The Journal of International Social Research/Volume $2 /$ 8 summer.

6. Oakley, P. and Garforth, C. (1985). Guide to Extension Training. Rome: Food and Agricultural Organization of the United Nations.

7. Rajasekaran, Bhakthavatsalam, (1993). A framework for incorporating indigenous knowledge systems into agricultural research and extension organizations for sustainable agricultural development in India. Retrospective Theses and Dissertations. Paper 10180.

8. Rivera, W.M. \& K. Qamar. (2003). Agricultural Extension, Rural Development and the Food Security Challenge. Rome: FAO.

9. Warrix, M. B. and Bocanegra, M. (1998). Keys to Building Successful Training Programs for Hispanic Family
Day
Care
Providers.
December
1998.
36
(6).
Journal
of Extension.http://www.joe.org/joe/1998december/a4.html. 